Valóságos könyvtár - könyvtári valóság. Könyvtár- és információtudományi tanulmányok 2018. Szerk. Kiszl Péter, Csík Tibor.

Budapest, ELTE BTK Könyvtár- és Információtudományi Intézet. 2018. 91-101.

\title{
PÉNZÜGYI KULTÚRA, VÁLLALKOZÁSFEJLESZTÉS, KÉPZÉS: A KÖNYVTÁR MINT A GAZDASÁGI FEJLÖDÉS EGYIK ZÁLOGA
}

\author{
KISZL PÉTER
}

ELTE BTK KITI, intézetigazgató egyetemi docens

\section{TARTALMI ÖSSZEFOGLALÓ}

Egy ország polgárai pénzügyi tudásának gyarapítása stratégiai feladat, hiszen mind a lakosság, mind a vállalkozói szféra, ezáltal az egész nemzetgazdaság számára kiemelt jelentőséggel bírnak a kellő körültekintéssel meghozott pénzügyi döntések. Különösen igaz ez hazánkra, ahol a különböző felmérések és a gyakorlati tapasztalatok alapján a lakosság pénzügyi ismeretei jócskán fejlesztésre szorulnak. A tanulmány ismerteti a pénzügyi tudatosság előmozdítására indított, jelenleg is zajló magyarországi projekteket, feltárja a kapcsolódási pontokat a felsőfokú könyvtárosképzés képzési és kimeneti követelményei (KKK) - konkrétan az Eötvös Loránd Tudományegyetem (ELTE) könyvtártudományi oktatási programjai - és e megoldások között. Ezt követően bemutatja az ELTE Bölcsészettudományi Kar Könyvtár- és Információtudományi Intézetének témába vágó - modellértékű - kezdeményezéseit, amelyek szem előtt tartják a könyvtárak és a gazdasági szektor hosszú évek óta szorgalmazott, elmélyítésre szoruló kapcsolatainak katalizálását, a könyvtárosok szerepének növelését a vállalkozásfejlesztésben, illetve - intézményvezetői szinten - a gazdálkodási (és forrásszerzési) kompetenciák jelentőségét a közgyüjtemények hatékony működtetésében.

„Money management is a lifetime voyage.”

(Thinkig Money)

\section{Pénzügyi-kultúra, müveltség, tudatosság, jólét}

„Sajátos örökeséget cipel országunk, hiszen míg a nyolcvanas években a nyugat a „Monopoly” társasjátékon nôtt fel, addig nekünk nem maradt más, mint a szocialista gazdaságot jelképező" „,Gazdálkodj okosan!'”. A játék élményében nincs eltérés, a célokban viszont komoly különbség figyelhetö meg. Elóbbi esetében szállodákat, tereket kell vásárolnunk és a tönkretett konkurenciát beszereznünk, a magyar verziónál viszont a bútöszekéény és a nappali bútora jelenti a gyözelem kulcsát." A ,sajátos örökség" hatása az élet minden területén, így a könyvtárak világában is érezhető mind a mai napig. A régi beidegződések átformálása, a korszerű, gazdaságközpontú látásmód tudatosítása hatalmas és kitartó munkát igénylő, hosszú folyamat. Szólunk arról, hogy e célok eléréséhez miként járulhat hozzá az oktatás, illetve esetünkben a könyvtárosképzés. 


\section{KISZL PÉTER}

Mielőtt azonban erre rátérnénk, fontos behatárolnunk tanulmányunk kulcsfogalmát, a pénzügyi kultúrát, melyhez a Magyar Nemzeti Bank (MNB) 2008-as meghatározását hívjuk segítségül: „a pénæügyi ismeretek és készségek olyan szintje, amelynek segitségével az egyének képesek a tudatos és körültekintö döntéseikhez szü̈kséges alapvetöpénzüugyi információkat azonositani, majd azok megszerzése után azokat értelmezni, és ez alapján döntést hozni, felmérve döntésük lehetséges jövöbeni pénzügyi, illetve egyéb követkerzményeit. ’’ A pénzügyi kultúra, illetve az angol ,financial literacy” szakkifejezéshez jobban igazodóan, az egyes szakértők szerinti pénzü̈gyi müveltség definiálásával számos nemzetközi ${ }^{3}$ és hazai közlemény ${ }^{4}$ foglalkozik. Lényegüket leegyszerűsítve: mindennek van pénzügyi vonzata, és szinte minden korosztály akár naponta is, több pénzügyi döntés meghozatalára kényszerül, így a pénzügyi ismeretek gyakorlati alkalmazása alapvető jelentőséggel bír a társadalom számára a mindennapi pénzügyi „jólét” elérése érdekében.

\section{Nemzetközi kutatások - Magyarország helye a mezónyben}

A 2008-as pénzügyi válság óta számos elemzés született, elsősorban a Gazdasági Együttmúködési és Fejlesztési Szervezet (OECD) ${ }^{5}$ és a Világbank ${ }^{6}$ kezdeményezésére a pénzügyi tudatosság témakörében, melyek részletes ismertetésére most nincs módunk. Kiemeljük azonban, hogy a több országra kiterjedő vizsgálatok megállapításai egybehangzóan mutatják: „Magyarországon a lakosság pénzügyi ismereteinek szintje elmarad a kivánatostól."

Az Európai Unió (EU) pénzügyi kultúrát érintő - főként a fogyasztóvédelemhez kapcsolódó - törekvései is rámutatnak az egyes tagállamok közti különbözőségekre, ${ }^{8}$ illetve az ennek megszüntetése érdekében végrehajtandó, az Európai Parlament és az Európai Bizottság által is felismert, folyamatosan napirenden tartott feladatokra. ${ }^{9}$

\section{Pén₹ügyi oktatási programok - külföldi és hazai gyakorlatok}

A pénzügyi tudatosságot szolgáló kompetenciafejlesztés világszerte prioritást élvez, ennek okát nem kell magyarázni. Az is evidencia, hogy az eddig ismertetett szervezetek mindegyike katalizálja a pénzügyi oktatási programok kidolgozását és múködtetését, ahogy társadalmi felelősségvállalásuk keretében a piaci szereplők is egyre inkább elkötelezettek nemcsak a lakosság, hanem a vállalkozói szektor vonatkozó ismereteinek - a digitális korszakra tekintettel is történő - bővítésére. ${ }^{10}$ Több nemzetközi merítésú kiadvány jelent meg a jó gyakorlatok összegyüjtésére és bemutatására, illetve útmutatásként az egyes nemzetek számára. ${ }^{11}$

Magyarországon 2012-ben - a lakosság devizában való eladósodása kapcsán - született országgyúlési határozat arról, hogy a Kormány „épitse be az általános iskolák felső tagozatai, valamint a középfokú iskolák tananyagába a pénzü̈gyi rendszer alapismereteire vonatkozó pénzügyi szabályok oktatását, a banki tranzakciók minimális követelményeinek a megismertetését és a fogyasztóvédelmi jogok tanitását." "12 A Nemzeti Alaptantervben (NAT) azonban jelenleg 
csak a szakgimnáziumokban jelenik meg kötelező pénzügyi tantárgy, máshol közismeretiként, választható jelleggel szerepel az órakínálatban. ${ }^{13}$

Az Állami Számvevőszék (ÁSZ) kutatásai meghatározók a témában. ${ }^{14}$ Figyelemre méltó a Magyar Nemzeti Bank Fogyasztóvédelmi Központjának komplex tevékenysége, mely a kalkulátorok múködtetésétől kezdve a rövid oktatófilmek, reklámok terjesztésén és a személyes tanácsadáson keresztül egészen a civil és felsőoktatási ötletpályázatokig terjed. ${ }^{15}$ A Magyar Államkincstár JátéKincstár nevű applikációja a diákok befektetési ismereteinek játékos formában történő bővítését célozza meg. ${ }^{16}$

2015-től Magyarország is csatlakozott az „Európai Pénzhét” (European Money Week) rendezvénysorozathoz, 2017-tól az Emberi Erőforrások Minisztériuma (EMMI) a projektgazdája a köznevelésre fókuszáló „Pénz7 - Pénzügyi és Vállalkozói Témahét”-nek. ${ }^{17}$

A téma szempontjából fontos mérföldkő, hogy 2017-től hét évre szóló, kétéves cselekvési tervekre bontott országos szintű stratégia segíti a pénzügyi tudatosság fejlesztését, mely figyelembe veszi az OECD által közölt, bevált gyakorlatokat. ${ }^{18}$ A szakértői anyag hangsúlyozza, hogy „Miköz̧ben a pénzügyi ismeretek tekintetében Magyarország lakossága más országokhoz képest nincs komoly lemaradásban, a pénzüigyekhez való hozzáállása, szemlélete és tényleges magatartása (pén zügyi döntései) szempontjából a nemzetközi rangsor utolsó harmadában sz̧erepel."19

A friss stratégia hatásai még nem értékelhetők, azonban megszületése előtt is számos - alulról építkezô - szakmai program dolgozott a pénzügyi tudatosság formálásán, közülük a legjelentősebbek és fő profiljuk:

- OTP Fáy András Alapítvány (1992-ben az OTP Bank hívta életre) - Középiskolások Országos Pénzügyi és Gazdasági Oktatóközpontja (OK Oktatási Központ) Budapesten és Nyíregyházán, középiskolákba utazó oktatói hálózat, tematikus tréningek, e-learning, tesztek, kvízek, ötletpályázat, mentorprogram, pedagógusklub, Sulibank Élményportál, karriertanácsadás; ${ }^{20}$

- Pénziránytú Alapítvány (alapítók: Diákhitel Központ, Magyar Bankszövetség, MNB; 2008) - általános- és középiskolások számára tankönyv- és tartalomfejlesztés (Iránytű a pénzügyekhez), nyári táborok, tanár-továbbképzés, PénzOkos Kupa, online játékos feladatok, BankVelem;

- Econventio Kerekasztal Közhasznú Pénzügyi Egyesület (magánszemélyek alapították 2010-ben) - webes pénzügyi vetélkedő, ismeretterjesztő táborok középiskolásoknak, tesztek felnőtteknek; ${ }^{21}$

- PénzSztár Hazai és Határon Túli Magyar Középiskolák Pénzügyi, Gazdasági és Vállalkozási Versenye (önszerveződő vetélkedő, neves szakértői testülettel és versenybizottsággal, támogatókkal) - éves verseny, tananyagokkal, felkészülést támogató segédletekkel, konferenciák, klubdélutánok, oktatói workshopok; ${ }^{22}$

- Magyar Bankszövetség - a Pénz7 projekt egyik szervezője.

Az Állami Számvevőszék 2016-os kutatási jelentésében tette közzé a hazai pénzügyi tudatosságot szolgáló képzési programokra vonatkozó, kérdőíves felmerésből levont következtetéseit, mely megerősíti az általunk leírtakat: azaz az országos hatókörrel bíró 
szervezetek programjai rendszerint a közoktatásban tanulókat szólítják meg, a leginkább rászoruló - például munkanélküli - felnőtt csoportokat viszont nem. A rövid időtartamú (pár órás) programok túlsúlya mellett a webes feladatmegoldások népszerűek, melyek csoportmunkában zajlanak, illetve vetélkedők, élményközpontú formák szolgálják a pénzügyi ismeretek átadását. A tematikák általában elérhetők, a tananyagok már kevéssé. ${ }^{23}$

\section{A péñügyi kultúra és a könyvtárak}

A mai könyvtár már nem csak a könyvek tára, szerepe kiszélesedett. ${ }^{24}$ Tengerentúli példák tucatjával lehet bizonyítani, hogy a közkönyvtári hálózat sikeresen kapcsolódhat be a társadalom pénzügyi mûveltségének pallérozásába. ${ }^{25} \mathrm{Az}$ Amerikai Könyvtári Egyesület Használói- és Tájékoztató Szolgáltatások Szervezete Üzleti Tájékoztató és Információszolgáltató Szekciójához (American Library Associaton = ALA, Reference and User Services Association = RUSA, Business Reference and Services Section = BRASS) kötődően 2014-ben adta ki Financial Literacy Education in Libraries című, meghatározó jelentőségű, a Múzeumi és Könyvtári Szolgáltatások Intézete (Institute of Museum and Library Services) által támogatott módszertani kötetét. ${ }^{26}$ A különféle kompetenciafejlesztő programötleteket felvonultató dokumentum fő fejezetei a következők:

1. Jövedelem

2. Hitelfelvétel, hitelezés

3. Megtakarítás és befektetés

4. Kiadások, költségek

5. Kockázatok, biztosítás

6. Pénzügyi műveltség oktatása a könyvtárban: jó gyakorlatok

7. Mellékletek (annotált bibliográfia, kulcskompetenciák, szakkifejezések magyarázata, mentorálási példák)

Az ALA Befektetési Oktatási Alapítvány (Investor Education Foundation = FINRA) támogatásával Smartinvesting@your library projektet múködtet az Amerikai Egyesült Államok könyvtáraiban, mely segít eligazodni a pénzügyek világában. ${ }^{27}$ A könyvtári hálózat tagjai számára modellprogramok, tréningek (webinárok, online kurzusok) segítik a tájékoztató munkát. A Thinkig Money című utazó pénzügyi kiállítás („A traveling exhibition to U.S. public libraries”) pedig 2016-2018 között ötven amerikai közkönyvtárba jut el. ${ }^{28}$

Az amerikai Közkönyvtári Egyesület (Public Library Association) önálló linkgyüjteményt épít a pénzügyi kultúra témakörében. ${ }^{29}$

A magyarországi könyvtárakban egyelőre gyerekcipőben járnak az üzleti információs szolgáltatásokat katalizáló kezdeményezések. A rendszerváltás időszakában ígéretes programok indultak, amelyek azonban nem bizonyultak hosszú távon életképesnek. ${ }^{30}$ Láthattuk, hogy a pénzügyi műveltség fejlesztésére ható hazai projektek sem számolnak a bibliotékákkal. 
PÉNZÜGYI KULTÚRA, VÁLLALKOZÁSFEJLESZTÉS, KÉPZÉS: A KÖNYVTÁR....

Pénzügyek a könyvtár-és információtudományi képzésben

A felsőoktatásban a Miskolci Egyetem úttörő szerepét hangsúlyozzák a mai elemzések, ahol 2017-ben Pén₹ügyi kultúra címmel önálló tárgyat vezettek be, ${ }^{31}$ 2018-ban pedig Fintelligence Pénzügyi Oktatási Centrumot adtak át, melynek ,célja az üzleti kultúrának és a lakossági pénzügyi tudatosságának fejlesztése, küldetése pedig az üj kutatási eredmények, az innovativ technológiák, a modern fizetési rendszerek folyamatos megismerése és azok továbbitása, kommunikációja. "’2

A könyvtárosképzésnek nincs szégyellnivalója. ${ }^{33}$ A gazdasági, pénzügyi ismeretek már az 1990-es években megjelentek a főiskolai és egyetemi tematikákban, valamint a tanfolyamokon. ${ }^{34}$ Terjedelmi okokból részletes történeti áttekintésre most nincs lehetôség, így az Eötvös Loránd Tudományegyetem Bölcsészettudományi Karának (ELTE BTK) jelenlegi gyakorlatára fókuszálunk. Az ELTE hálótervében 2001 óta jelenik meg a témakör, kezdetben a Tájékoztatás, információforrások kurzusok és speciálkollégiumok keretében, ${ }^{35}$ majd a bolognai típusú rendszerre áttérve, 2006 óta önálló tantárgy fejleszti a kapcsolódó készségeket, beleértve a ráépülő vállalkozásfejlesztési jellegű stúdiumokat is, melyek nem hiányozhatnak napjaink modern könyvtárosképzéséből. ${ }^{36}$ A 2018-ban érvényes, témához kapcsolódó tantárgykínálat maradéktalanul igazodik a hatályos képzési és kimeneti követelményekben (KKK) leírtakhoz, ${ }^{37}$ amelyet a képzőintézmények, a szakmai szervezetek és a hallgatók együttműködésével 2015-2016-ban alkottunk meg: ${ }^{38}$

Informatikus könyvtáros BA

(KKK szakmai jellemző: menedzsment ismeretek; 5-20 kredit)

információ- és tudásmenedzsment, EU-információ specializációk

- Gazdasági, vállalkozói, jogi alapismeretek

- Üzleti információ 1-2.

- Gazdasági szakirodalmi információ

Könyvtártudomány MA

(KKK szakmai jellemző: gazdasági és vezetési ismeretek, szervezetfejlesztés; 5-15 kredit)

Minden hallgató számára kötelező:

- Gazdasági ismeretek

- Piacgazdaság és könyvtárügy az információs társadalomban

- Minőségmenedzsment

Kutatás-fejlesztési információmenedzsment specializáció

- Közgazdaságtudományi és jogi tájékoztatás

Üzleti információmenedzser specializáció

- Üzleti és jogi ismeretek

- Az üzleti információ elmélete és gyakorlata

- Szervezeti információgazdálkodás, térítéses információszolgáltatás 
KISZL PÉTER

- Forrásszerzési, pályázatkészítési múhelymunka

- Projektmunka 1-2.

A foglalkozásokat rendszeresen vendégelőadók bevonásával - akik nemcsak a könyvtári szektorból, hanem a versenyszférából is érkeznek - szervezi a Tanszék. A szakmai együttműködésben részt vevő szervezetek közül kiemeljük az Infodok Kft.-t, a Magyar Telekom Nyrt. információszolgáltató partnerét.

A pénzügyi kompetenciafejlesztésre kell támaszkodnia a vállalkozási ismeretek átadásának. A gazdaság múködési mechanizmusával már tisztában lévő hallgatóknak - a magyar könyvtárosképzésben újdonságként - vezettük be információs kisvállalkozások létrehozásának és működtetésének modellezését. ${ }^{39}$ Az oktatás életközeliségét tanúsítja, hogy a félév végén gyakorló szakemberek értékelik az egyes cégek kreativitását, piacképességét és teljesítményét. ${ }^{40}$

Tematikus összeállítások jelentek meg a szaksajtóban, ${ }^{41}$ szakdolgozati ${ }^{42}$ és doktori $(\mathrm{PhD})$ témaválasztások, ${ }^{43}$ tudományos diákköri (TDK) szereplések ${ }^{44}$ és egyéb szakmai aktivitási formák ${ }^{45}$ bizonyítják a hallgatók egyértelmú érdeklődését. A könyvtárosképzésben fokozottan fel kell készíteni a hallgatókat a pályázatkészítési, forrásszerzési tevékenységekre is, melyek elengedhetetlen velejárói akár a forprofit, akár a nonprofit szektorban való boldogulásnak. ${ }^{46}$

Könyvtárvezetés - gazdálkodási ismeretekkel, üqleti kapcsolatokkal

„Ha igazán hatékonyan szeretnének müködni a könyvtárak, nem tehetik az üzleti szeletor kizárásával. ’47 - hangsúlyozta 2018 tavaszán Markója Szilárd, az Országgyűlési Könyvtár vezetője a Piacgazdaság és könyvtárügy az információs társadalomban címú mesterszakos kurzus vendégelőadójaként. Az általa elmondottakat erôsíti az is, hogy Magyarországon minden jogász vagy közgazdász végzettséggel nem rendelkező - magasabb könyvtári vezetőnek „államháztartási és vezetési ismereteket nyújtó tanfolyamot kell elvégeznie." A8 A kör bezárult.

\section{Jegyzetek és irodalom}

1. MOLNÁR József: Vállalkozz okosan! = Spiritusz Campus Magazin, 6. évf. 3. sz. 2008. 8. p.

2. Együttmúködési megállapodás a pénzügyi kultúra fejlesztés területén. MNB-PSZÁF. 2008. április 15. 1. p. Forrás: https://www.mnb.hu/letoltes/0415mnbpszafmegallpodas-penzugyikultura-fejleszte.pdf [2018. május 7.]

3. Pl.: CUDE, Brenda J.: Financial literacy 501. = The Journal of Consumer Affairs. 44. vol. 2. no. 2010. 271-275. p. Forrás: https://doi.org/10.1111/j.1745-6606.2010.01168.x és STOLPER, Oscar A. - WALTER, Andreas: Financial literacy, financial advice, and financial behavior. $=$ Zeitschrift Für Betriebswirtschaft, 87. vol. 5. no. 2017. 581-643. p. Forrás: http://dx.doi.org/10.1007/s11573-017-0853-9 [2018. május 7.] Elméleti fejezetében további nemzetközi kiindulópontok a pénzügyi kultúra meghatározására: KOVÁCS Péter - 
PÉNZÜGYI KULTÚRA, VÁLLALKOZÁSFEJLESZTÉS, KÉPZÉS: A KÖNYVTÁR....

CSERI Cserne - ORSZÁG Gáborné: ECONVENTIO teszt. Célcsoportok összehasonlítása 2015. 4-11. p. Forrás: http://www.econventio.hu/download/1224/econventio-teszt2015_3-korcsoport_eredmenyei.docx [2018. május 7.]

4. Pl.: HUSZ Ildikó - SZÁNTÓ Zoltán Oszkár: Mi a pénzügyi kultúra? In: Meddig nyújtózkodjunk? A magyar háztartások és vállalkozások pénzügyi kultúrájának változása a válság időszakában. Szerk. Czakó Ágnes, Husz Ildikó, Szántó Zoltán. Budapest, BCE Innovációs Központ Nonprofit Kft., 9-14. p. és BÁRCZI Judit - ZÉMAN Zoltán: A pénzügyi kultúra és annak anomáliái. $=$ Polgári Szemle, 11. évf. 1-3. sz. 2015. Forrás: https://polgariszemle. hu/archivum/93-2015-junius-11-evfolyam-1-3-szam/gazdasagpolitika/651-a-penzuegyikultura-es-annak-anomaliai [2018. május 7.]

5. OECD/INFE International Survey of Adult Financial Literacy Competencies 2016. 95 p. Forrás: http://www.oecd.org/finance/oecd-infe-survey-adult-financial-literacy-competencies.htm és ZSÓTÉR Boglárka - NÉMETH Erzsébet - LUKSANDER Alexandra: A társadalmi-gazdasági környezet változásának hatása a pénzügyi kultúrára. Az OECD 2010-es és 2015-ös kutatási eredményeinek összehasonlítása. = Pénzügyi Szemle, 62. évf. 2. sz. 2017. 251-266. p. Forrás: https://www.penzugyiszemle.hu/documents/zsoter-nemetluksander-2017-2-mpdf_20170717153812_98.pdf [2018. május 7.]

6. Financial literacy survey. Report on the key findings of the survey prepared for the World Bank. June 2010. Sofia, Bulgaria, Alpha Research. 190 p. Forrás: https://openknowledge. worldbank.org/handle/10986/12876 [2018. május 7.] és Financial capability surveys around the world. Why financial capability is important and how surveys can help. The World Bank. 8 p. Forrás: http://responsiblefinance.worldbank.org/ /media/GIAWB/FL/Documents/ Publications/Why-financial-capability-is-important.pdf [2018. május 7.]

7. NÉMETH Erzsébet [et al.]: Pénzügyi kultúra fejlesztési programok felmérése. Kutatási jelentés. 2016. április. Budapest, Állami Számvevőszék, 2016. 43. p. Forrás: https://www. asz.hu/storage/files/files/Publikaciok/Elemzesek_tanulmanyok/2016/penzugyi_kult_ fejl_programok.pdf?download=true [2018. május 7.] Vö.: Szánalmas a magyarok pénzügyi tudása, és még finoman fogalmaztunk. Portfolio, 2016. október 14. Forrás: https://www. portfolio.hu/befektetes/ongondoskodas/szanalmas-a-magyarok-penzugyi-tudasa-es-megfinoman-fogalmaztunk.238645.html [2018. május 7.]

8. MULLER, Patrice [et al].: Consumer protection aspects of financial services. Brussels, European Union, 2014. Forrás: http://www.europarl.europa.eu/RegData/etudes/etudes/ join/2014/507463/IPOL-IMCO_ET\%282014\%29507463_EN.pdf [2018. május 7.] doi: $10.2861 / 3221$

9. VALANT, Jana: Improving the financial literacy of European consumers. Briefing. May 2015. European Parliamentary Research Service. Members' Research Service. PE 557.020 Forrás: http://www.europarl.europa.eu/RegData/etudes/BRIE/2015/557020/EPRS_ BRI(2015)557020_EN.pdf [2018.május 7.]

10. PATWARDHAN, Anju - SINGLETON, Ken - SCHMITZ, Kai: Financial inclusion in the digital age. Including list of 100 leading financial technology companies promoting financial inclusion. March 2018. Forrás: https://responsiblefinanceforum.org/wpcontent/uploads/2018/03/FinancialInclusionintheDigitalAge.pdf [2018. május 7.]

11. OECD International gateway for financial education. Forrás: http://www.financial-education. org/standards.html [2018. május 7.] Good Practices for Financial Consumer Protection. 


\section{KISZL PÉTER}

June 2012. Washington, The World Bank. Forrás: http://siteresources.worldbank.org/EXTFINANCIALSECTOR/Resources/Good_Practices_for_Financial_CP.pdf [2018. május 7.]; RUTLEDGE, Susan L.: Good practices for consumer protection and financial literacy in Europe and Central Asia. A diagnostic tool. Washington, The World Bank. 2010. ECSPF Working Paper 001 http://siteresources.worldbank.org/INTECAREGTOPPRVSECDEV/Resources/GoodPractices_August2010.pdf Financial Education - National strategies in Europe good practices report. Published at the launch of the first European Money Week. March 2015. Forrás: https://www.ebf.eu/wp-content/uploads/2017/01/ GoodPracticesReport_EuropeanMoneyWeek-FINAL.pdf [2018. május 7.]

12. 31/2012. (IV. 3.) OGY határozat a lakossági deviza-eladósodás megakadályozásához szükséges kormányzati intézkedésekről. Forrás: https://mkogy.jogtar.hu/jogszabaly?docid=a12h0031. OGY [2018. május 7.]

13. Vö.: Pénzügyileg tudatos generáció felnevelése a cél. Kormányzat. Nemzetgazdasági Minisztérium. 2018. március 19. Forrás: http://www.kormany.hu/hu/nemzetgazdasagiminiszterium/hirek/penzugyileg-tudatos-generacio-felnevelese-a-cel [2018. május 7.]

14. NÉMETH Erzsébet szerk.: Az Állami Számvevőszék szerepe a pénzügyi kultúra fejlesztésében. Projektfüzet. Budapest, Állami Számvevőszék, 2014. Forrás: https://www.asz. $\mathrm{hu} /$ storage/files/files/Szakmai\%20kutat\%C3\%A1s/2014/t366.pdf?ctid=744 [2018. agugusztus 8.]

15. Pénzügyi Fogyasztóvédelmi Központ. MNB. Forrás: https://www.mnb.hu/fogyasztovedelem [2018. május 7.]

16. Új szolgáltatást indított a Kincstár. Magyar Államkincstár. Forrás: http://www.allamkincstar. gov.hu/hu/oldalak/tartalom/5928 [2018. május 7.]

17. Pénz7. Forrás: http://www.penz7.hu [2018. május 7.]

18. Pénzügyi tudatosság fejlesztésének stratégiája. 2017. Forrás: http://www.kormany.hu/ download/5/39/21000/P\%C3\%A9nz\%C3\%BCgyi\%20tudatoss \%C3\%A1g\%20 fejleszt $\% \mathrm{C} 3 \% \mathrm{~A} 9 \mathrm{~s} \% \mathrm{C} 3 \% \mathrm{~A} 9 \mathrm{nek}^{\circ} \% 20$ strat $\% \mathrm{C} 3 \% \mathrm{~A} 9 \mathrm{gi} \% \mathrm{C} 3 \% \mathrm{~A} 1$ ja.pdf [2018. május 7.$]$

19. Uo. 16. p.

20. 1188/2017. (IV. 10.) Korm. határozat a fiatalok pénzügyi tudatosságát növelő oktatási kompetenciák támogatásáról. Forrás: https:// net.jogtar.hu/jogszabaly?docid=A17H1188.KOR \&timeshift=fffffff4\&txtreferer=00000001.TXT [2018. május 7.]

21. Econventio. Forrás: http://econventio.hu [2018. május 7.]

22. PénzSztár. Forrás: http://penzsztar.hu és HORVÁTH Ilona: A nemzetközi és hazai pénzügyi, gazdasági oktatás eredményei a kutatások tükrében. A PénzSztár verseny mint a pénzügyi, gazdasági műveltség fejlesztésének sajátos lehetősége. = Új Pedagógiai Szemle. 67. évf. 7-8. sz. 2017. 18-43. p. Forrás: http://folyoiratok.ofi.hu/sites/default/files/journals/ upsz_2017_7_8.pdf [2018. május 7.]

23. A programok hatékonyságát számos szakcikk veszi górcső alá, pl.: NÉMETH Erzsébet [et al.]: Körkép és kórkép a pénzügyi kultúra fejlesztését célzó képzésekrool. = Pénzügyi Szemle, 61. évf. 2. sz. 2016. 407-428. p. Forrás: https://www.penzugyiszemle.hu/documents/ nemeth-2016-3pdf_20161214122212_31.pdf [2018. május 7.] és NÉMETH Erzsébet: Pénzügyi kultúrát fejlesztő képzések: felmérés és diagnózis. = Új Pedagógiai Szemle, 67. évf. 7-8. sz. 2017. 46-68. p. Forrás: http://folyoiratok.ofi.hu/sites/default/files/journals/ upsz_2017_7_8.pdf [2018. május 7.] 
PÉNZÜGYI KULTÚRA, VÁLLALKOZÁSFEJLESZTÉS, KÉPZÉS: A KÖNYVTÁR....

24. KISZL Péter: Könyvtárak a közösségért - New Yorkban. = Tudományos és Műszaki Tájékoztatás, 61. évf. 9. sz. 2014. 315-330. p. Forrás: http://tmt.omikk.bme.hu/tmt/article/ view/433 [2018. május 7.] és KISZL Péter: Ki viszi át...? A könyvtárak társadalmi felelősségvállalása a digitális korban. = Tudományos és Műszaki Tájékoztatás, 64. évf. 1. sz. 2017. 1-23. p. Forrás: http://tmt.omikk.bme.hu/tmt/article/view/774 [2018. május 7.]

25. BELL, Lori [et al.]: Financial information literacy services at your library. = Searcher. 17. vol. 6. no. 2009.18-21., 53. p., RIZK, Daad A. - BOWEN, Cathy F.: Libraries and financial literacy programs. $=$ Journal of Business and Librarianship, 20. vol. 1-2. no. 2015. 1-6. p. Forrás: https://doi.org/10.1080/08963568.2015.978722 és FAULKNER, Ashley E.: Financial literacy education in the United States. Library programming versus popular personal finance literature. $=$ Reference \& User Services Quarterly, 56. vol. 2. no. 2016. 116-125. p. Forrás: https://journals.ala.org/index.php/rusq/article/view/6189/8028 [2018. május 7.]

26. Financial literacy education in libraries. Guidelines and best practices for service. ALA RUSA BRASS. 2014. Forrás: http://www.ala.org/rusa/sites/ala.org.rusa/files/content/ FLEGuidelines_Final_September_2014.pdf [2018. május 7.] és KIT, Keller [et al.]: Meeting the need for library-based financial literacy education. = Reference \& User Services Quarterly, 54. vol. 3. no. 2015. 47-51. p. Forrás: https://journals.ala.org/rusq/article/ download/5643/6974 [2018. május 7.]

27. Smart investing@your library. Forrás: http://smartinvesting.ala.org [2018. május 7.]

28. Thinking Money. Forrás: https://apply.ala.org/thinkingmoney [2018. május 7.]

29. Financial Literacy. ALA Public Library Association. Forrás: http://www.ala.org/pla/ resources/tools/programming-instruction/financial-literacy [2018. május 7.]

30. Bővebben: KISZL Péter: Hogyan tovább? Üzleti információszolgáltatás a magyarországi könyvtárakban. = Tudományos és Műszaki Tájékoztatás, 51. évf. 9. sz. 2004. 371-378. p. Forrás: http://tmt.omikk.bme.hu/tmt/article/view/1143 [2018. május 7.]

31. A korábban már említett nemzeti stratégia (Pénzügyi tudatosság fejlesztésének stratégiája) célul tűzi ki ennek kötelező kiterjesztését a magyar felsőoktatásra, ld. 19. p. Kapcsolódó kiadvány: PÁL Zsolt: A pénzügyi kultúra aktuális kérdései, különös tekintettel a banki szolgáltatásokra. Miskolc, A közgazdaságtani-módszertani képzés fejlesztéséért Alapítvány, 2017. Forrás: http://www.penz7.hu/uploads/images/ckfinder/files/tanulmanykotetfinal. pdf [2018. május 7.]

32. Fintelligence Pénzügyi Oktatási Centrumot adtak át a Miskolci Egyetemen. Forrás: http:// www.uni-miskolc.hu/hirek/1604/fintelligence_penzugyi_oktatasi_centrumot_adtak_ at_a_miskolci_egyetemen [2018. május 7.]

33. Vö. MIHALKOVNÉ SZAKÁCS Katalin: A kompetens vállalkozásoktató pedagógus. A vállalkozásoktatás eredményessége és hatékonysága a felsőoktatásban. = Vezetéstudomány, 46. évf. 8. sz. 2015. 57-66. p.

34. Részletesen: KISZL Péter: Business - informatikus könyvtáros hallgatóknak. A vállalkozói, üzleti információ oktatása a felsőfokú könyvtárosképzésben. = Tudományos és Műszaki Tájékoztatás, 51. évf. 11. sz. 2004. 484-494. p. Forrás: http://tmt.omikk.bme.hu/tmt/ article/view/1656 [2018. május 7.]

35. Az ezredforduló fejleményeiről tudósít: KISZL Péter: Vállalkozói, üzleti információforrások című kurzus az ELTE BTK Könyvtártudományi - Informatikai Tanszékén. = Könyv, 
Könyvtár, Könyvtáros, 11. évf. 5. sz. 2002. 28-33. p. és KISZL Péter: Üzleti információs ismeretek könyvtáros hallgatóknak. = Könyvtári Levelező/lap, 15. évf. 7. sz. 2003. 21-22. p.

36. A témakör kifejtését ld.: KISZL Péter: Üzleti információ, céginformáció és a könyvtárak. Budapest, ELTE, 2005.

37. 18/2016. (VIII. 5.) EMMI rendelet a felsőoktatási szakképzések, az alap- és mesterképzések képzési és kimeneti követelményeiről, valamint a tanári felkészités közös követelményeiről és az egyes tanárszakok képzési és kimeneti követelményeiről szóló 8/2013. (I. 30.) EMMI rendelet módosításáról. Forrás: https://net.jogtar.hu/jogszabaly?docid=A1600018.EMM \&timeshift=fffffff4\&txtreferer=00000001.TXT [2018. május 7.]

38. KISZL Péter: Újratervezés a könyvtárosképzésben. = Tudományos és Múszaki Tájékoztatás, 62. évf. 11-12. sz. 2015. 399-414. p. Forrás: http://tmt.omikk.bme.hu/tmt/article/ view/605 [2018. május 7.] és KISZL Péter: Könyvtártudomány 2017-től - a katedra szemszögéből. = Könyv és Nevelés, 19. évf. 1. sz. 2017. 26-37. p. Forrás: http:// folyoiratok.ofi. hu/konyv-es-neveles/konyvtartudomany-2017-tol-a-katedra-szemszogebol [2018. május 7.]

39. Kiszl Péter vonatkozó kurzusairól ld.: HABÓK Lilla: Információs vállalkozások a bölcsészkaron. = KIT Hírlevél, 2009. május 13. Forrás: http://www.kithirlevel.hu/index. php?kh=informacios_vallalkozasok_a_bolcseszkaron [2018. május 7.] és BENEDEK Janka: Az információs kisvállalkozások trendjei az ELTE hallgatóinak projektmunkái alapján. Szakdolgozat. Budapest, ELTE BTK, 2010. (témavezető: Kiszl Péter). A 2017. decemberi értékelésről szóló bloghír: Információs kisvállalkozások és könyvtárosok. Forrás: http://elte-lis. blogspot.com/2018/01/informacios-kisvallalkozasok-es.html [2018. május 7.]

40. A felsőoktatási intézmények ma már rendszeresen hirdetnek hasonló tanfolyamokat (pl. Start-up és innovációmenedzsment-múhelymunka). Forrás: https://www.elte.hu/content/ start-up-es-innovacio-menedzsment-muhelymunka.t.5877 [2018. május 7.] vagy pályázatokat (pl. ELTE Innovatív hallgatói ötletpályázat). Forrás: https://www.elte.hu/content/ innovativ-hallgatoi-otletpalyazat-2018-hatarido-hosszabbitas.t.15803 [2018. május 7.]. Itt kell megemlíteni a Fiatal Vállalkozók Szövetsége (FIVOSZ: https://fivosz.hu) tevékenységét és az OFA Nonprofit Kft. Vállalkozz itthon fiatal! programját http://ofa.hu/ vallalkozz-itthon-fiatal [2018. május 7.]

41. Pl. Tudományos és Műszaki Tájékoztatás, 56. évf. 6. sz. 2009. Korszerú menedzsment eljárások tematikus szám Juhász Éva, Horváth Sarolta és Tóth Gabriella egyetemi szakdolgozatai alapján készült tanulmányokkal (témavezető: Kiszl Péter) Forrás: http://tmt-archive. omikk.bme.hu/issue.html@issue_id=505.html [2018. május 7.]

42. Két friss példa a jelenleg készülő mesterszintű szakdolgozatokból: FARKAS Csenge: Információs szakemberek az üzleti szférában és NEMESHÁZY Marcell: Az üzleti információszolgáltatás helye a közkönyvtárakban (mindkettő témavezetője: Kiszl Péter).

43. Pl. JUHÁSZ Éva: Könyvtárgazda(g)ság: pénzügyi vonatkozású korszerű menedzsment eljárások könyvtári alkalmazása című készülő doktori disszertációja (témavezető: Kiszl Péter).

44. BENEDEK Janka: A jövő információmenedzsereinek reklám és marketingstratégiai elképzelései. OTDK. Különdíj. 2011. (témavezető: Barátné Hajdu Ágnes és Kiszl Péter)

45. Az év turisztikai témájú szakdolgozata 2011 pályázaton különdíjas: VÖRÖS Ildikó: A siófoki városi könyvtár marketingtevékenysége és az idegenforgalom nyújtotta lehetôségek (témavezető: Kiszl Péter). Átadták „Az év turisztikai témájú szakdolgozata 2011” pályázat díjait. Forrás: https://turizmus.com/szallashely-vendeglatas/atadtak-az-ev-turisztikai-temaju- 
szakdolgozata-2011-palyazat-dijait-1103888 [2018. május 7.] Több kapcsolódó hallgatói tanulmány: KISZL Péter szerk.: Trendek a hazai és nemzetközi könyvtárügyben. Eger, Líceum Kiadó, 2013.

46. Ennek keretében támogatjuk pl. az Egyetemi Könyvtárért Alapítvány tevékenységét: KISZL Péter: Könyvtártudomány elméletben és gyakorlatban - intézményi együttmúködés az Eötvös Loránd Tudományegyetemen. = Tudományos és Műszaki Tájékoztatás. 61. évf. 7-8. sz. 2014. 262-263. p. Forrás: http://tmt.omikk.bme.hu/tmt/article/view/407 [2018. május 7.] és KISZL Péter: Alapítvány a könyvtárért: közgyűjteményi forrásteremtés civil eszközökkel. = Tudományos és Múszaki Tájékoztatás. 62. évf. 6. sz. 2015. 239-241. p. http://tmt. omikk.bme.hu/tmt/article/view/210 [2018. május 7.]

47. „Ha igazán hatékonyan szeretnének múködni a könyvtárak, nem tehetik az üzleti szektor kizárásával." - Markója Szilárd intézetünkben. ELTE LIS. Forrás: http://elte-lis.blogspot.com/ 2018/05/ha-igazan-hatekonyan-szeretnenek.html [2018. május 7.]

48. 50/1992. (XI. 20.) Korm. rendelet a közalkalmazottak jogállásáról szóló 1992. évi XXXIII. törvény végrehajtásáról a művészeti, a közművelődési és a közgyűjteményi területen foglalkoztatott közalkalmazottak jogviszonyával összefüggô egyes kérdések rendezésére 6/G. \ (1) és (3). Forrás: https://net.jogtar.hu/jogszabaly?docid=99200150.kor [2018. május 7.] A Könyvtári Intézet által szervezett „Államháztartási és vezetési ismeretek többfunkciós kulturális intézmények vezetői számára” képzésről bővebben: https:/ ki.oszk.hu/tanfolyamok/allamhaztartasi-es-vezetesi-ismeretek-tobbfunkcios-kulturalis-intezmenyek-vezetoi [2018. május 7.]

Kiszl Péter könyvtáros és közgazdász végzettségű habilitált egyetemi docens, az ELTE BTK Könyvtár- és Információtudományi Intézetének igazgatója, az Információtudományi Tanszék és a Könyvtártudományi Doktori Program vezetője, az informatikus könyvtáros BA és a könyvtártudomány MA szak felelőse. Kutatási területei: információ- és tudásmenedzsment, üzleti információ, könyvtárosok és információs szakemberek vállalkozói kompetenciájának fejlesztése. 